\title{
Effect of airborne pollution of cement factory and brick kilns on human health in Bokajan area
}

\author{
Darshana Chetia and Bijoylaxmi Bhuyan
}

Received: 16.07.2020; Revised: 10.10.2020; Accepted: 24.10.2020

See end of the paper for authors' affiliations

\section{Darshana Chetia}

Department of Family Resource Management and Consumer Science, Assam Agricultural University, Jorhat (Assam) India Email : chetiadarshana@gmail. com
ABSTRACT : Cement and brick manufacturing include emissions of airborne pollution during operation and production which can cause tremendous effect on human health and environment. Thus, this study was undertaken with the aim to study the health condition of the workers working in the cement factory and brick kiln of Bokajan, Assam and their adoption rate of safety measures. A total of 80 workers (40 numbers of workers exposed to cement dust and another 40 numbers of brick manufacturing workers) were randomly selected for the study. Data were gathered by personal interview and observation method. The findings of the study depicted that the workers of the cement factory and brick kiln of Bokajan were exposed to industrial dust and smoke for prolonged period, causing different health problems on them. Adoption rate of the safety measures was very poor among the brick kiln workers, while the cement factory workers fairly adopted few safety measurers provided by the factory. The study recommends proper preventive measures and awareness for health and wellbeing of the workers which would increase work efficiency and productivity.

KEY WORDS: Airborne pollution, Cement factory, Brick kilns, Human health

- HOW TO CITE THIS PAPER : Chetia, Darshana and Bhuyan, Bijoylaxmi (2020). Effect of airborne pollution of cement factory and brick kilns on human health in Bokajan area. Asian J. Home Sci., 15 (2) : 199-205, DOI: 10.15740/HAS/AJHS/15.2/199-205. Copyright@ 2020: Hind Agri-Horticultural Society. 